\title{
Analisis Pengaruh Kegiatan Promosi Terhadap Ekuitas Merk Universitas Buddhi Dharma Di Kalangan Mahasiswa (Survei pada mahasiswa program Studi Manajemen)
}

\author{
Agus Kusnawan \\ Manajemen, Universitas Buddhi Dharma, Banten, Indonesia
}

\begin{abstract}
ABSTRAK
Dari hasil pengujian dan pengolahan data diperoleh besaran korelasi advertaising ditunjukkan dengan nilai koefisien korelasi sebesar 0.514, personal selling ditunjukkan dengan nilai koefisien korelasi sebesar 0.558 , korelasi sales promotion ditunjukkan dengan nilai koefisien korelasi sebesar 0.695 , korelasi public relation ditunjukkan dengan nilai koefisien korelasi sebesar 0.652 ,korelasi direct marketing ditunjukkan dengan nilai koefisien korelasi sebesar 0.537dimana kelima korelasi tersebut medekati nilai 1 korelasi yang kuat dan positif. dilihat bahwa Kolom R untuk model 1 menunjukkan bahwa angka koefisien korelasi yaitu sebesar 0.652 Hal ini berarti korelasi antara Advertaising, personal seling,sales promotion, public relation dan direct marketing terhadap ekuitas merk Universitas Buddhi Dharma dan kolom $\mathrm{R}$ Squareatau koefisien determinasi0.425, hal ini berarti besarnya pengaruh Advertaising, personal seling, sales promotion, public relation dan direct marketing terhadap ekuitas merk Universitas Buddhi kolom $\mathrm{R}$ untuk model 2 menujukkan bahwa angka koefisien korelasi yaitu sebesar 0.697, hal ini berarti korelasi antara Advertaising, personal seling, sales promotion, public relation dan direct marketing terhadap ekuitas merk Universitas Buddhi Dharma adalah kuat dan kolom R Square untuk model 2 menujukkan angka 0.486, hal ini berarti besarnya pengaruh Advertaising, personal seling, sales promotion, public relation dan direct marketing terhadap ekuitas merk Universitas Buddhi Dharma adalah sebesar 48.6 \%. Kolom R untuk model 3 menujukkan bahwa angka koefisien korelasi yaitu sebesar 0.717 hal ini berarti korelasi antara Advertaising, personal seling, sales promotion, public relation dan direct marketing terhadap ekuitas merk Universitas Buddhi Dharma adalah kuat.Kolom R Square untuk model 3 menunjukan angka R Square adalah $51.4 \%$.Untuk uji pengaruh secara simultan didapat $\mathrm{F}$ hitung37.880dengan tingkat signifikan 0.000 dimana angka $0.000<0.05$ dan juga $F$ hitung $>F$ tabel atau $37.880>3.09$, dengan demikian Ho ditolak dan Ha diterima artinya terdapat pengaruh linear antara variabel Advertaising, personal seling, sales promotion, public relation dan direct marketing dengan ekuitas mertk Universitas Buddhi Dharma, maka model regresi tersebut sudah layak dan tepat untuk memprediksi ekuitas merkUniversitas Buddhi Dharma. Persamaan regresi diperoleh $Y=a+0,835+0,446 .+0,713+0,347+0,382$.Pada kolom $t$ diketahui bahwa $t_{\text {hitung }}$ untuk Advertaising, personal selling, sales promotion, public relation dan direct marketing masing-masing adalah sebesar 5,879,3.086,4.737,2.326,2.130 tabel $\mathrm{t}$ adalah 1,984. Oleh karena $\mathrm{t}_{\text {hitungAdvertaising, }}$ personal seling, sales promotion, public relation dan direct marketing lebih besar dari $t t_{\text {tabel }}$ atau $>1,984$, maka Ho ditolak dan Ha diterima.
\end{abstract}

Kata kunci: Ekuitas Merk; Promosi; Universitas Buddhi Dharma 


\title{
Analysis of the Effect of Promotion Activities on the Brand Equity Brands of the Buddhi Dharma University Among Students (Survey on Management Studies program students)
}

\begin{abstract}
From the result of testing and data processing, the correlation coefficient of advertaising is 0.514 , personal selling is shown with the correlation coefficient value of 0.558 , correlation of sales promotion is shown by correlation coefficient value of 0.695 , correlation of public relation is indicated by correlation coefficient value of 0.652, Direct marketing correlation is indicated by correlation coefficient value of 0.537 whereas the five correlations are based on a strong and positive correlation value. seen that Column $R$ for model 1 shows that the correlation coefficient value is 0.652 This means the correlation between Advertaising, personal promotion, sales promotion, public relation and direct marketing to the brand equity of the Buddhi Dharma University and the R column or the coefficient of determination0.425, this means the influence of Advertaising, personal seling, sales promotion, public relation and direct marketing to the brand equity of the University of Buddhi column $R$ for model 2 shows that the coefficient of correlation is 0.697 , this means the correlation between Advertaising, personal promotion, sales promotion, public relation and direct marketing to the brand equity of the Buddhi Dharma University is strong and the R Square column for model 2 shows the number 0.486, which means the influence of Advertaising, personal promotion, sales promotion, public relation and direct marketing to the brand equity of the Buddhi Dharma University is $48.6 \%$. Column $R$ for model 3 shows that the correlation coefficient value of 0.717 means that the correlation between Advertaising, personal seling, sales promotion, public relation and direct marketing to the brand equity of the Buddhi Dharma University is strong. The R Square Column for model 3 shows $R$ Square is $51.4 \%$. For simultaneous influence test it is obtained by F count 0,0080 with a significant level 0.000 where $0.000<0.05$ and $F$ count $>F$ table or 37.880> 3.09, thus $\mathrm{Ho}$ is rejected and $\mathrm{Ha}$ is accepted means there is a linear influence between Advertaising variable, personal sales promotion, public relation and direct marketing with the equity of Mertk Buddhi Dharma University, the regression model is already feasible and appropriate to predict the equity of the Dharma Buddhi University. The regression equation is $Y=a+0,835$ $+0,446 .+0,713+0,347+0,382$. In column $t$ it is known that $t$ count for Advertaising, personal selling, sales promotion, public relation and direct marketing are 5,879,3,086,4.737, 2.326,2.130 table $t$ is 1,984. Because the calculation of Advertaising, personal seling, sales promotion, public relation and direct marketing is greater than $t$ table or $>1,984$, then Ho is rejected and Ha is accepted.
\end{abstract}

Keyword: Brand Equity; Promotion; Buddhi Dharma University 


\section{PENDAHULUAN}

Dewasa ini pertumbuhan dan perkembangan Perguruan Tinggi Swasta di Indonesia telah semakin berkembang. Hal ini dapat diamati dari semakin beragamnya jenis dan bentukserta program studi yang ditawarkan oleh masing-masing perguruan tinggi swasta. Mulai dari program studi Diloma tiga,diploma empat,strata satu,strata dua dan strata tigaoleh pegruruan tinggi sawasta yang baru telah mapan sampai perguruan tinggi swasta baru berdiri, sehingga alternatif pilihan konsumen atau calon mahasiswa yang dapat memenuhi kebutuhan akan program studi yang ditawarkan.

Ketatnya persaingan di bisnis diantara perguruan tinggi swasta ini tidak menyebabkan menurunnya minat para penyelengara untuk terjun dalam bisnis pendidikan ini. Karena bisnis perguruan tinggi ini memiliki prospek yang cerah di masa yang akan datang, Mengingat nilai pasarnya yang relatif besar dan pertumbuhan penduduk yang tinggi, pertumbuhan tersebut dapat dipahami karena terdapat beberapa faktor demografis yang mendukung diantaranya penduduk Indonesia yang berjumlah sekitar 200 juta orang ditambah dengan permintaan dari persuahaan untuk syarat calon tenaga kerjas menjadikan negara ini sebagai pasar yang ideal bagi perguruan tinggi ini.

Perguruan tinggi swasta ini dapat dibagi menjadi beberapa bagian yaitu jalur vokasi dan akademik di luar kursus-kursus yang didirikan oleh berbagai pihak dan memperoleh ijin bukan dari Kemenristek Dikti. Salah satu prodi yang sedang digalakan oleh pemerintah adalah jalur vokasi walaupun di luar vokasi yaitu jalur akademik yang masih mengalami peningkatan pertumbuhan yang cukup besar dan meluas. Dalam beberapa tahun saja contohnya perguruan tingi swasta yang berdiri bukan di wilayah Kopertis perguruan tinggi itu sekarang sudah merambah dan mengembangkan serta membuka kampus cabangya di wilayah Kopertis yang berbeda, dimana ijin pembukaan cabang itu di wilayah lain akan berdampak terhadap pertumbuhan perguruan tinggi swasta yang telah beridiri sesuai dengan domisilinya atau wilayah Kopertis yang menaunginya. Salah satu hal penting yang dilakukan oleh manajemen perguruan tinggi swasta adalah berbagai kegiatan promosi yang dilancarkannya. Kegiatan promosi tersebut ditujukan kepada masyarakat 
calon mahasiswa untuk semakin memperkenalkan program studi yang dimiliki oleh masing-masing perguruan tinggi swasta khusunya UBD. Dengan mengelola dan memiliki nama yang kuat tentunya selain akan mempertahankan mahasiswa loyal juga akan memudahkan dalam merebut dan memperoleh mahasiswa baru. Ketenaran nama yang kuat memiliki asset dan liabilitas yang nilainya sangat tinggi bagi UBD. Salah satu aset tak terwujud adalah ekuitas yang dimiliki merek UBD, Bagi banyak perguruan tinggi swasta, merek dan segala yang diwakilinya merupakan aset yang paling penting karena sebagai dasar keunggulan kompetitif dan sumber kemajuan pada masa depan.

Ekuitas merek menurut Aaker (1997 : 22) adalah seperangkat asset dan liabilitas merek yang berkaitan dengan suatu merek, nama dan simbolnya yang menambah atau mengurangi nilai yang diberikan oleh sebuah barang atau jasa kepada perusahaan atau pelanggan perusahaan. Sedangkan ekuitas merek menurut Knapp (2001:2) adalah totalitas dan persepsi merek, mencakup kualitas relatif dari produk dan jasa, kinerja keuangan, loyalitas pelanggan, karyawan, dan semua stakeholder tentang merek. Salah satu faktor yang berpengaruh dalam peningkatan atau penurunan ekuitas merek dari suatu perguruan tinggi swasta adalah kegiatan promosi yang dilancarkan oleh PTS tersebut. Tujuan dari promosi selain untuk meningkatkan penjualan formulir adalah juga untuk menciptakan dan memelihara ekuitas merek yang dimiliki perguruan tinggi.

Oleh karena itu masalah yang melatarbelakangi penelitian di Universitas Buddhi Dharma adalah tidak diketahuinya seberapa kuat pengaruh kegiatan promosi yang dilakukan marketing terhadap peningkatan atau penurunan ekuitas merek UBD. Dengan terungkapnya pengaruh dari kegiatan promosi terhadap ekuitas merek, menjadi salah satu acuan manajemen UBD dalam upaya membangun merek atau nama.

Berdasarkan uraian tersebut diatas maka penulis tertarik untuk melakukan penelitian dan menuangkannya dalam penelitian yang berjudul :

"Analisis Kegiatan Promosi Terhadap Ekuitas Merk Universitas Buddhi Dharma Di Kalangan Mahasiswa (Survei pada mahasiswa program Studi Manajemen)"

\section{IDENTIFIKASI MASALAH}

Berdasarkan latar belakang yang diuraikan diatas, maka permasalahan yang akan 
dianalisis terbatas pada hal sebagai berikut: seberapa besar pengaruh kegiatan promosi terhadap ekuitas merek UBD di kalangan mahasiswa (survei pada mahasiswa program studi manajemen).

\section{MAKSUD DAN TUJUAN}

Maksud dari penelitian ini adalah untuk memperoleh data mengenai pelaksanaan kegiatan promosi yang dilakukan bagian marketing dan mengkaji pengaruhnya terhadap ekuitas merek secara keseluruhan.

Berdasarkan identifikasi masalah diatas, maka tujuan penelitian yang ingin dicapai adalah untuk : mengetahui seberapa besar pengaruh kegiatan promosi terhadap ekuitas merek UBD di Kalangan mahasiswa (survei pada mahasiswa prodi manajemen).

\section{LANDASAN TEORI}

\section{Definisi Bauran Promosi}

Setiap elemen dalam kegiatan promosi memiliki fungsi dan peranannya masingmasing, namun disamping dapat berdiri sendiri, setiap elemen tersebut akan menghasilkan dampak yang lebih kuat ketika dikombinasikan dengan elemen lainnya. Setiap elemen dalam bauran promosi memiliki hubungan yang erat antara yang satu dengan yang lainnya (Belch, 2001:22).

\section{Periklanan (Advertising)}

Iklan merupakan bentuk komunikasi tidak langsung, yang didasari pada informasi tentang keunggulan atau keuntungan suatu produk, yang disusun sedemikian rupa sehingga menimbulkan rasa menyenangkan yang akan mengubah pikiran seseorang untuk melakukan pembelian. Iklan berupaya untuk memberitahu dan mempengaruhi pelanggan tentang suatu produk.

Peranan periklanan dalam perencanaan promosi adalah penting. Periklanan baik itu dalam cakupan internasional maupun nasional, lokal maupun langsung perorangan (direct) adalah penting, karena periklanan memiliki kemampuan untuk menginformasikan, mengingatkan, membedakan atau mendorong terciptanya calon pelanggan maupun menjaga pelanggan tetap dari sebuah produk atau perusahaan (Fill, 1999:264).

\section{Personal Selling}

Personal selling merupakan komunikasi langsung atau komunikasi tatap muka antara PTS dan calon mahasiswa untuk memperkenalkan program studi kepada 
calon mahasiswa dan membentuk pemahaman terhadap program studi yang ada sehingga mereka kemudian akan mencoba untuk mendaftarkan diri (berupaya mendekati calon mahasiswa). Personal selling dapat terjadi jika adanya hubungan yang hidup, langsung dan interaktif antara 2 orang atau lebih, (Tjiptono, 1997:224).

\section{Sales Promotion (Promosi Penjualan)}

Promosi penjualan terdiri dari berbagai aktifitas promosi, termasuk pameran pendidikan, presentasi ke SMK/SMA sederajat. Promosi membutuhkan biaya yang relatif lebih kecil atau rendah dibandingkan biaya yang dikeluarkan PTS untuk melancarkan kegiatan periklanan. Kegiatan ini bertujuan untuk mendorong calon mahasiswa untuk melakukan pembelian formulir.

Menurut Tjiptono (2002:224) aktifitas personal selling memiliki beberapa fungsi sebagai berikut:

1. Prospecting, yaitu mencari pembeli dan menjalin hubungan dengan mereka.

2. Targeting, yaitu mengalokasikan kelangkaan waktu penjual demi pembelicommunicating, yaitu memberi informasi mengenai produk perusahaan kepada pelanggan.
3. Selling, yaitu mendekati, mempresentasikan dan mendemonstrasikan, mengatasi penolakan, serta menjual produk kepada pelanggan.

4. Servicing, yaitu memberikan berbagai jasa dan pelayanan kepada pelanggan.

5. Informating gathering, yakni melakukan riset dan intelejen pasar.

6. Allocating, yaitu menentukan pelanggan yang akan dituju.

\section{Public Relations}

Public relations merupakan upaya komunikasi menyeluruh dari suatu perguruan tinggi swasta untuk mempengaruhi persepsi, opini, keyakinan dan sikap berbagai kelompok orang terhadap PTS tersebut. Keberhasilan public relations ditentukan oleh pencapaian itikad baik, penerimaan, dan dukungan publik. Tujuan dari kegiatan ini adalah membangun dan memelihara citra PTS. Hubungan masyarakat (public relations) menurut Payne (2001:199) menyangkut beberapa tugas pemasaran, yang di dalamnya termasuk:

1. Membangun dan memelihara citra

2. Mendukung kegiatan komunikasi

3. Mengatasi problem dan masalah 
PRIMANOMIS : JURNAL EKONOMI DAN BISNIS - VOL. 16. NO. 1 (2018)

Versi Online Tersedia di : https://jurnal.buddhidharma.ac.id/index.php/PE

| 1412-632X (Cetak) | 2614-6789 (Online) |

4. Mempererat atau memperkuat Ekuitas Merek positioning

5. Mempengaruhi publik tertentu

6. Membantu peluncuran produk baru

Sedangkan alat-alat yang digunakan

Merek menurut Aaker (1997 : 7), juga dikutip oleh Cravens (2000:292) nama dan atau simbol yang bersifat membedakan (seperti sebuah logo, cap, atau kemasan) untuk mendesain suatu program dengan maksud mengidentifikasi barang hubungan masyarakat (public relations) atau jasa dan seorang penjual sebuah adalah:

produk tertentu, dengan demikian

1. Publikasi, termasuk wawancara membedakannya dan barang-barang dan terbuka, laporan tahunan, brosur, jasa yang dihasilkan pesaing.

poster dan artikel.

Ekuitas merek adalah sekelompok aset dan

2. Peristiwa khusus termasuk konferensi kewajiban yang dihubungkan dengan pers, seminar dan pidato.

sebuah merek, nama ataupun simbol yang

3. Hubungan investor yang ditujukan dapat menambah atau mengurangi nilai untuk memperoleh dukungan para dari produk atau jasa yang ditawarkan investor dan para analisis

(Cravens, 2000:292). Aset dan kewajiban

4. Pemberitaan di media. yang mempengaruhi ekuitas merek

5. Sponsorship berdalih bantuan dan termasuk di dalamnya loyalitas merek, proyek-proyek msyarakat.

\section{Direct Marketing}

Direct marketing memanfaatkan satu atau beberapa media iklan untuk menimbulkan respon yang terukur dan atau transaksi di kesadaran nama, kualitas yang dirasakan dan asosiasi merek. Dalam penelitian ini, penulis menggunakan konsep dari Aaker yang mengelompokkan ekuitas merek ke dalam lima ketegori / dimensi secara umum, yaitu:

sembarang lokasi (pemsaran yang bersifat interaktif). Direct marketing memadatkan semua kegiatan promosi dalam penjualan formulir secara langsung tanpa perantara. 


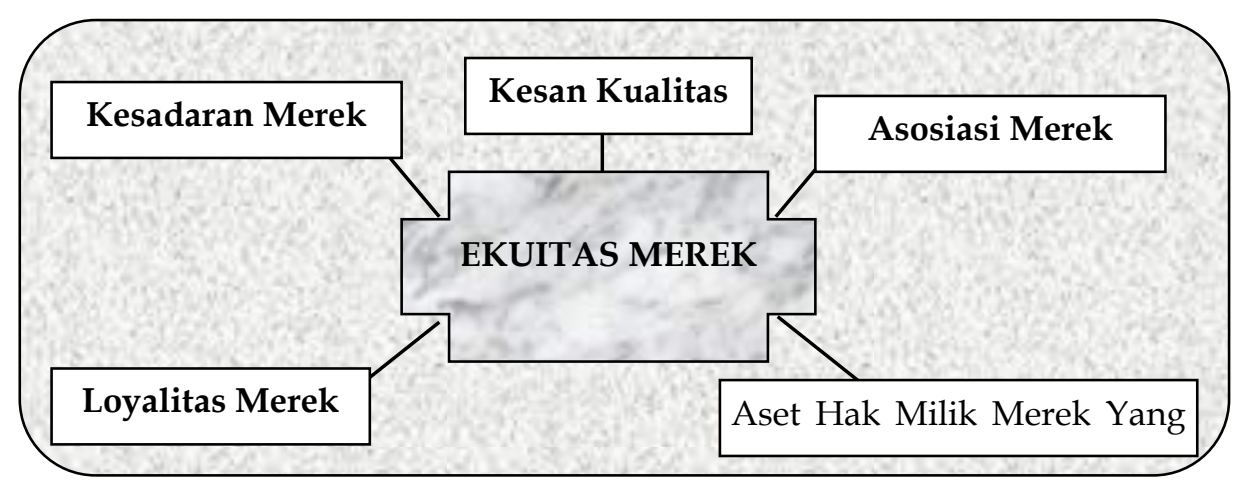

Gambar 1. Konsep Brand Equity

\section{Hubungan antar Variabel Bauran Pengaruh Kegiatan Promosi Terhadap Promosi Ekuitas Merek}

Belch mengungkapkan bahwa secara Beberapa teori mengatakan bahwa setiap tradisional promosi (promotion) terdiri dari elemen dalam bauran promosi memiliki lima elemen yakni: advertising, sales peranan dalam menciptakan dan promotion, publicity/public relations, personal memelihara ekuitas merek. Masingselling dan direct marketing. Setiap elemen masing elemen dalam bauran promosi memegang peranan yang penting dalam dapat berdiri sendiri atau pun secara program promosi yang terpadu, saling bersama-sama dalam mencapai tujuannya bergantung, dengan sifat dan kelebihan untuk membangun ekuitas merek tersebut. masing-masing yang berbeda antara satu Kombinasi antar berbagai elemen promosi dengan yang lainnya (Belch, 2001:14).

Setiap elemen dalam bauran promosi dengan proporsi yang disesuaikan dengan tujuan program promosi menghasilkan memiliki fungsi dan peranannya masing- yang disebut sebagai bauran promosi masing. Namun disamping dapat berdiri (Cravens, 2000:353),Tujuan dari sendiri, setiap elemen tersebut akan komunikasi pemasaran dalam hal ini menghasilkan dampak yang lebih kuat ketika dikombinasikan dengan elemen kegiatan promosi adalah untuk meningkatkan ekuitas dari merek lainnya. Setiap elemen dalam bauran perusahaan. Kita dapat melihat bahwa promosi memiliki hubungan yang erat ekuitas merek semakin bertambah melalui antara yang satu dengan yang lainnya program promosi yang menciptakan (Belch, 2001:22). kesadaran atas merek. Program promosi yang tepat akan membangun asosiasi yang 
baik, kuat dan unik dalam pikiran atau gagasan, program promosi juga konsumen antara merek tersebut dan dimaksudkan untuk membangun merek setiap figur serta manfaatnya (Shimp, perusahaan dengan meningkatkan dan 2000:260 dalam Sitorus, 2004:54) . memelihara ekuitas mereknya (Aaker, Paradigma Penelitian 1991:11)

Promosi bertujuan untuk menginformasikan program studi, jasa

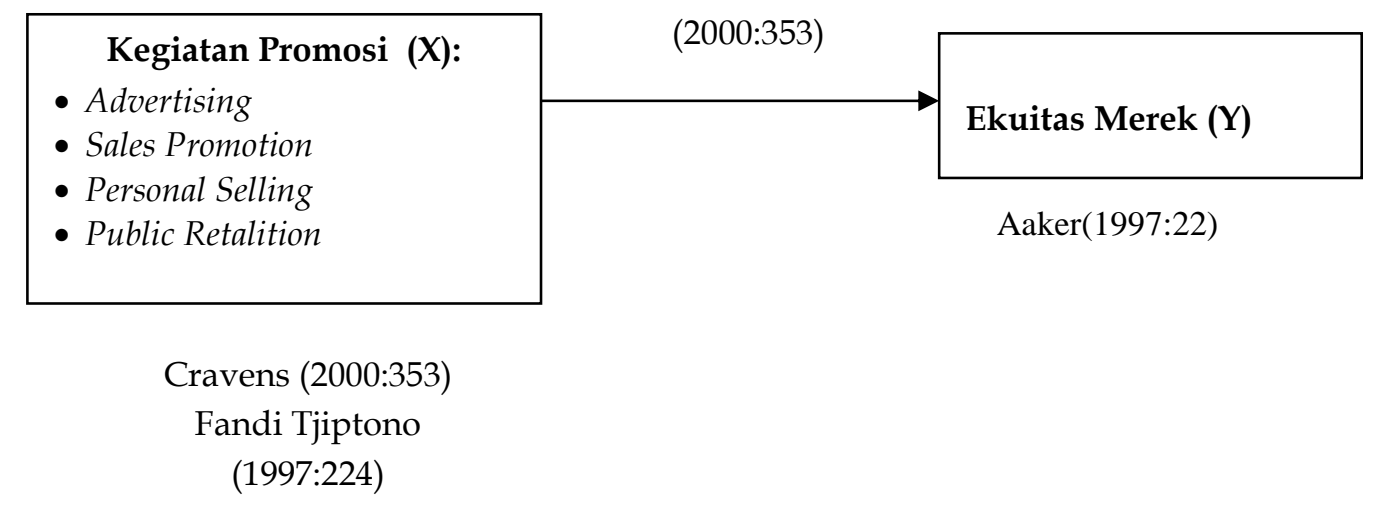

Gambar 2. Paradigma Penelitian

\section{METODOLOGI PENELITIAN}

\section{Teknik Pegumpulan Data}

Penelitian ini dilaksanakan melalui pengumpulan data di lapangan, maka metode penelitian yang digunakan adalah metode survey, yaitu informasi dari sebagian populasi dikumpulkan secara langsung di tempat kejadian dengan tujuan untuk mengetahui pendapat dari sebagian populasi terhadap aspek yang sedang diteliti (Indriantoro, 1999:26).

\section{Operasionalisasi Variabel Penelitian}

Operasionalisasi variabel penelitian terdiri dari variabel bebas (independent variabel) dan variabel tak bebas/terikat (dependent variabel). Dalam penelitian ini yang menjadi variabel bebas (independent variabel) adalah kegiatan bauran promosi $(\mathrm{X})$, dengan sub variabel penelitian adalah alat-alat promosi yakni: advertising $\left(\mathrm{X}_{1}\right)$, personal selling $\left(\mathrm{X}_{2}\right)$, sales promotion $\left(\mathrm{X}_{3}\right)$, dan public relation $\left(\mathrm{X}_{4}\right)$, Sedangkan yang sebagai variabel tak bebas/terikat (dependent variable) adalah ekuitas merek (Y). Operasionalisasi variabel tersebut dapat dijabarkan dalam tabel sebagai berikut: 


\section{Teknik Penarikan Sampel}

Teknik pengambilan sampel menurut Roscoe dalam buku research Methods For Business (1982:253) yang dikutip oleh Sugiyono (208: 129) memberikan saran tentang ukuran sampel untuk penelitian seperti berikut :

1. Ukuran sampel yang layak dalam penelitian adalah antara 30 sampai dengan 500

2. Bila sampel dibagi dalam kategori (missal : pria-wanita, pegawai negeriswasta dan lain-lain) maka jumlah anggota sampel setiap ketegori minimal 30.

3. Bila dalam penelitian akan melakukan analisis dengan multivariate (korelasi atau regresi ganda misal), maka jumlah anggota sampel minimal 10 kali dari jumlah variable yang diteliti. Misal variable penelitiannya ada 5 (independen + dependen), maka jumlah anggota sampel $=10 \times 5=50$

4. Untuk penelitian eksperimen yang sederhana, yang menggunakan kelompok eksperimen dan kelompok kontrol, maka jumlah anggota sampel masing-masing antara 10 s/d 20.

\section{Prosedur Pengumpulan Data}

Konsumen dalam hal ini adalah mahasiswa program studi Manajemen Universitas Buddhi Dharma yang merupakan sumber data primer dari penelitian ini. Setiap konsumen diberikan kuesioner untuk mengungkap tanggapan atas pelaksanaan bauran promosi dan ekuitas merek. Data yang diambil bersifat data primer yang dilakukan dengan menyebarkan kuesioner kepada konsumen. Data tersebut juga bersifat cross-sectional (Kuncoro 2003:126), artinya data tersebut merupakan data yang diambil pada satu titik waktu tertentu Kesimpulan penelitian yang akan ditarik merupakan kesimpulan atas hal-hal yang berlaku terhadap keseluruhan populasi. Adalah hal yang sulit mengukur keseluruhan populasi, untuk itu pendekatan yang terbaik untuk menjelaskan sifat-sifat populasi adalah menggunakan pendekatan statistik. Pendekatan statitik membutuhkan sampel sebagai sumber data yang menjadi acuan dalam analisis kemudian. Menurut Sugiono (2003:81) sampel yang akan digunakan sebagai sumber data tersebut harus memiliki parameter dengan kata lain parameternya dapat dihitung, (antara lain; 
rata-rata, simpangan baku, varians dan koefisien korelasi).

Prosedur pengumpulan data yang digunakan dalam penelitian ini adalah sebagai berikut:

\section{Data Primer}

a. Kuesioner:

Dilakukan untuk mengetahui pendapat dan tanggapan dari konsumen. Daftar pertanyaan untuk kuesioner dibuat dalam bentuk sederhana dengan dua metode. Metode pertanyaan terbuka, yaitu pertanyaan yang tidak menggiring responden kepada jawaban yang alternatifnya sudah ditetapkan dan metode pertanyaan tertutup, yaitu pertanyaan yang akan menggiring responden kepada jawaban yang alternatifnya sudah ditetapkan. Untuk mengumpulkan data, peneliti membuat kuesioner dan menyebarkan di perusahaan, adapun respondennya adalah para mahasiswa. Bentuk jawaban dari pertanyaan yang digunakan dalam kuesioner ini adalah jawaban dengan skala ordinal dalam skala yang berjumlah lima (dikenal juga dengan skala Likert). Skala ini berisikan seperangkat pertanyaan yang merupakan pendapat responden. Mengenai variabelvariabel obyek penelitian, dimana tanggapan positif diberi nilai atau skor paling besar (5) dan pelanggan dengan menggunakan teknik wawancara mendalam (depth interview) yang berhubungan dengan penelitian yang dilakukan.

b. Observasi

Melakukan penelitian dan observasi secara langsung terhadap kegiatan dan keadaan dari perusahaan. tanggapan negatif diberi nilai atau skor paling kecil (1).

c. Wawancara

Wawancara dilakukan dengan pihak manajemen dan

2. Data sekunder.

Penelitian dilakukan dengan cara mencari, mempelajari bahan-bahan yang terdapat di buku, majalah, internet serta berbagai sumber lainnya yang berkaitan dengan masalah yang tengah diteliti.

\section{Metode Analisis Data}

Langkah terakhir dari metode penelitian ini adalah analisis data. Di mana kegiatan analisis data yang dilakukan peneliti 
merupakan kegiatan setelah data dari seluruh responden terkumpul.

\section{Method of Successive Interval (MSI)}

Data yang terkumpul dari hasil wawancara kuesioner diolah dan dikelompokkan kedalam tiga proses analisa yaitu: persiapan, tabulasi, dan penerapan data pada pendekatan penelitian. Persiapan adalah mengumpulkan dan memeriksa kebenaran cara pengisian. Kemudian melakukan tabulasi hasil kuesioner sesuai dengan penilaian yang telah ditetapkan dengan menggunakan skala ordinal skala lima, hasil angka yang didapat adalah sebagai indikator untuk variabel bebas $\mathrm{X}_{1}$ (advertising), $\mathrm{X}_{2}$ (personal selling), $\mathrm{X}_{3}$ (sales promotion), $\mathrm{X}_{4}$ (public relation dan variabel terikat Y (ekuitas merek) yaitu seperti berikut $\left(\mathrm{X}_{1} ; \mathrm{Y}\right),\left(\mathrm{X}_{2} ; \mathrm{Y}\right),\left(\mathrm{X}_{3} ; \mathrm{Y}\right),\left(\mathrm{X}_{4} ; \mathrm{Y}\right)$, dan data yang didapat diterapkan pada pendekatan penelitian yang digunakan sesuai dengan tujuan penelitian, untuk mengetahui pengaruh kegiatan promosi terhadap ekuitas merek. Untuk mendapatkan data variabel kualitatif yaitu unsur-unsur dari kegiatan promosi, maka setiap variabel dijabarkan ke dalam subsub variabel dan kemudian dioperasionalkan ke dalam indikator yang setiap indikator diukur dengan skala ordinal.

Dengan menggunakan analisa jalur sebagai alat untuk mengetahui pengaruh kegiatan promosi terhadap ekuitas merek UBD, dan karena data yang diambil melalui kuesioner menggunakan pernyataan skala Likert, maka data yang didapat diubah menjadi berskala ordinal, oleh karena itu data tersebut perlu ditransformasikan terlebih dahulu menjadi bentuk interval yaitu dengan menggunakan "Method of Successive Interval" (Harun Al Rasyid, 1996) sehingga dapat digunakan untuk analisa jalur.

\section{Uji Validitas dan Reliabilitas Instrumen}

Di dalam suatu penelitian, data memiliki kedudukan yang penting karena data merupakan penggambaran variabelvariabel yang diteliti dan berfungsi sebagai alat pembuktian hipotesis. Dengan demikian benar tidaknya data sangat menentukan hasil penelitian. Sementara benar atau tidaknya data tergantung kepada baik tidaknya instrumen pengumpul data yang antara lain harus memenuhi dua persyaratan yaitu validitas dan reliabilitas. 


\section{Rancangan Pengujian Hipotesis}

Metode analisis jalur (Path Analysis)

digunakan untuk menjelaskan pasangan

data dari variabel independen dan variabel

dependen dari semua sampel penelitian untuk pengujian hipotesis. Metode ini digunakan dengan tujuan untuk mengetahui besarnya hubungan dan pengaruh antar variabel $X_{1}, X_{2}, X_{3}$, dan $X_{4}$, serta pengaruh variabel $\mathrm{X}_{1}, \mathrm{X}_{2}, \mathrm{X}_{3}$, dan $\mathrm{X}_{4}$, terhadap variabel $Y$, kemudian setiap variabel $X_{1}, X_{2}, X_{3}$, dan $X_{4}$ diukur pengaruhnya terhadap variabel $\mathrm{Y}$ untuk mendapatkan gambaran mengenai perbandingan pengaruh yang paling signifikan, serta menghitung Koefisien Jalur secara Partial dan simultan.

\section{HASIL PENELITIAN}

Pada penelitian ini penulis mengambil beberapa responden untuk dijadikan sampel dalam menjawab pernyataanpernyataan yang diajukan mengenai kegiatan promosi terhadap Ekuitas Merk Universitas Buddhi Dharma dalam bentuk beberapa pernyataan atau kuesioner yang diajukan kepada 83 responden yaitu mahasiswa Universitas Buddhi Dharma.

\section{Uji Validitas dan Reliabilitas dan Reliabilias}

Dari pengujian terhadap variabel Adertaising sebesar 0,712, Personal Selling sebesar 0,772, Sales promotion sebesar 0,750,Public Ralation sebesar 0,769, Direct marketing sebesar 0,771 dan Ekuitas Merk sebesar 0,771, maka daata tersebut dapat dikatakan realiabel karena memiliki nilai alpha cronbach diatas 0.70 dan nilai hasil uji validitas memiliki angka di atas 0.195 sehingga semua pernyataan sudah valid.

\section{Analisa Kegiatan Promosi Terhadap Ekuitas Merk Univertsitas Buddhi Dharma.}

Untuk mengetahui ada tidaknya pengaruh antara variabel $\times 1$ (advertaising), variabel X2 (personal seling), variable X3 (sales promotion), variable $\mathrm{X} 4$ (public relation), variable X5 (direct marketing) dengan variabel Y (ekutitas merk) serta mengukur kuat tidaknya pengaruh tersebut, maka digunakan analisa regresi linear berganda dengan menggunakan perhitungan SPSS (Statistical Package for Service Softition), berikut ini hasil analisis regresi linear berganda adalah sebagai berikutn dimana Besar korelasi advertaising ditunjukkan dengan nilai koefisien korelasi sebesar 0.514 mendekati 1, dimana korelasi yang positif dan kuat. Besar korelasi personal seling (X2) ditunjukkan dengan nilai koefisien korelasi sebesar 0.558 mendekati 1, dimana korelasi yang positif dan kuat. Besar korelasi sales promotion (X3) ditunjukkan dengan nilai koefisien korelasi sebesar 0.695 mendekati 1, dimana korelasi yang positif.Besar korelasi public relation (X4) ditunjukkan dengan nilai koefisien korelasi sebesar 0.652 mendekati 1, dimana korelasi yang 
positif dan kuat. Besar korelasi direct marketing (X5) ditunjukkan dengan nilai koefisien korelasi sebesar 0.537 mendekati 1, dimana korelasi yang positif dan kuat. Jadi korelasi X1,X2,X3,X4,X5 adalah kuat dan mempunyai korealsi yang positif. Hal ini berarti dapat dikatakan bahwa Advertaising, personal seling,sallies promotion, public relation dan direct marketing harus lebih baik untuk meningkatkan ekuitas merk Universitas Buddhi Dharma. Arah korelasi yang positif menunjukan semakin baik Advertaising, personal seling,sallies promotion, public relation dan direct marketing akan membuat ekuitas merk Universitas Buddhi Dharma semakin meningkat. Demikian pula sebaliknya, semakin buruk Advertaising, personal seling,sallies promotion, public relation dan direct marketing akan semakin menurun ekuitas merk Universitas Buddhi Dharma.

Dari hasil pengujian koefesien determinasi diperoleh angka sebesar 0,514 atau 51,4 \% diamana besarnya pengaruh Advertaising, personal seling, sales promotion, public relation dan direct marketing terhadap ekuitas merkUniversitas Buddhi Dharma adalah (51,4\%) sedangkan sisanya $48,6 \%$ dipengaruhi faktor lain. $\mathrm{R}$ Square berkisar pada 0 sampai 1 , semakin kecil angka $R$ Square menunjukkan semakin kuat pengaruh antara variabel dan sebaliknya.

Untuk mengetahui pengaruh secara parsial dari kelima variavel tersebut didapat $\mathrm{F}$ hitung 27.882 dengan tingkat signifikan 0,000 dimana angka $0.000<0.05$ dan juga $F_{\text {hitung }}>\mathrm{F}$ tabel atau $27.882>3.09$, dengan demikian Ho ditolak dan $\mathrm{Ha}$ diterima artinya terdapat pengaruh linear antara variabel Advertaising, personal seling, sales promotion, public relation dan direct marketing terhadap ekuitas Universitas Buddhi Dharma, maka model regresi tersebut sudah layak dan tepat untuk memprediksi ekuitas merk Universitas Buddhi Dharma.

Dari hasil uji perhitungan persamaan regresi sebagai berikut $\mathrm{Y}=$ $0,271+0,835+0,446+0,347+0,382$, dimana pada saat variabel X1 (advertaising) terjadi peningkatan atau penurunan sebesar 1 poin maka variabel Y (Ekuitas Merk Universitas Buddhi Dharma) akan mengalami peningkatan atau penurunan sebesar 0,835, pada saat variabel X2 (Personal Seling) terjadi peningkatan atau penurunan sebesar 1 poin maka variabel $Y$ (Ekuitas Merk Universitas Buddhi Dharma) akan mengalami peningkatan atau penurunan sebesar 0,446,pada saat variabel X3 (Sale Promotion) terjadi peningkatan atau penurunan sebesar 1 poin maka variabel Y (Ekuitas Merk Universitas Buddhi Dharma) akan mengalami peningkatan atau penurunan sebesar 0,713, pada saat variabel X4 (Public relation) terjadi peningkatan atau penurunan sebesar 1 poin maka variabel $Y$ (Ekuitas Merk Universitas Buddhi Dharma) akan mengalami peningkatan atau penurunan sebesar 0,347,pada saat variabel X5 (Direct Marketing) terjadi peningkatan atau penurunan sebesar 1 poin maka variabel $Y$ (Ekuitas Merk Universitas Buddhi Dharma) akan mengalami peningkatan atau penurunan sebesar 0,382 . 
Dan hasil pengujian secara simultan diperoleh angka $\mathrm{F}$ hitung sebesar 27,882 artinya dimana $\mathrm{F}$ hitung lebih besar dari Ftabel ada pengaruh atas variabel $x 1, x 2, x 3, x 4, x 5$ terhadap $Y$ dan dari hasil uji pengaruh secara parsial dimana diketahui bahwa $t_{\text {hitung untuk Advertaising, personal }}$ seling, sales promotion, public relation dan direct marketing masing-masing adalah sebesar $\quad 5,879,3.086,4.737,2.326,2.130$ dengan menggunakan tabel distribusi normal $\mathrm{t}$ dan menggunakan tingkat keyakinan pengujian $(1-a)$ sebesar 95\% dan tingkat kesalahan (a) n - 2 = 83-2=81, maka diperoleh nilai distribusi tabel $t$ adalah 1,984. Oleh karena $t_{\text {hitungAdvertaising, personal seling, sales }}$ promotion, public relation dan direct marketing lebih besar dari $\mathrm{t}$ tabel atau > 1,984, maka Ho ditolak dan Ha diterima. Sedangkan untuk mengetahui hasil pengujian kausal untuk variabel kegiatan promosi dapat di lihat pada tabel berikut ini :

Tabel 1. Korelasi

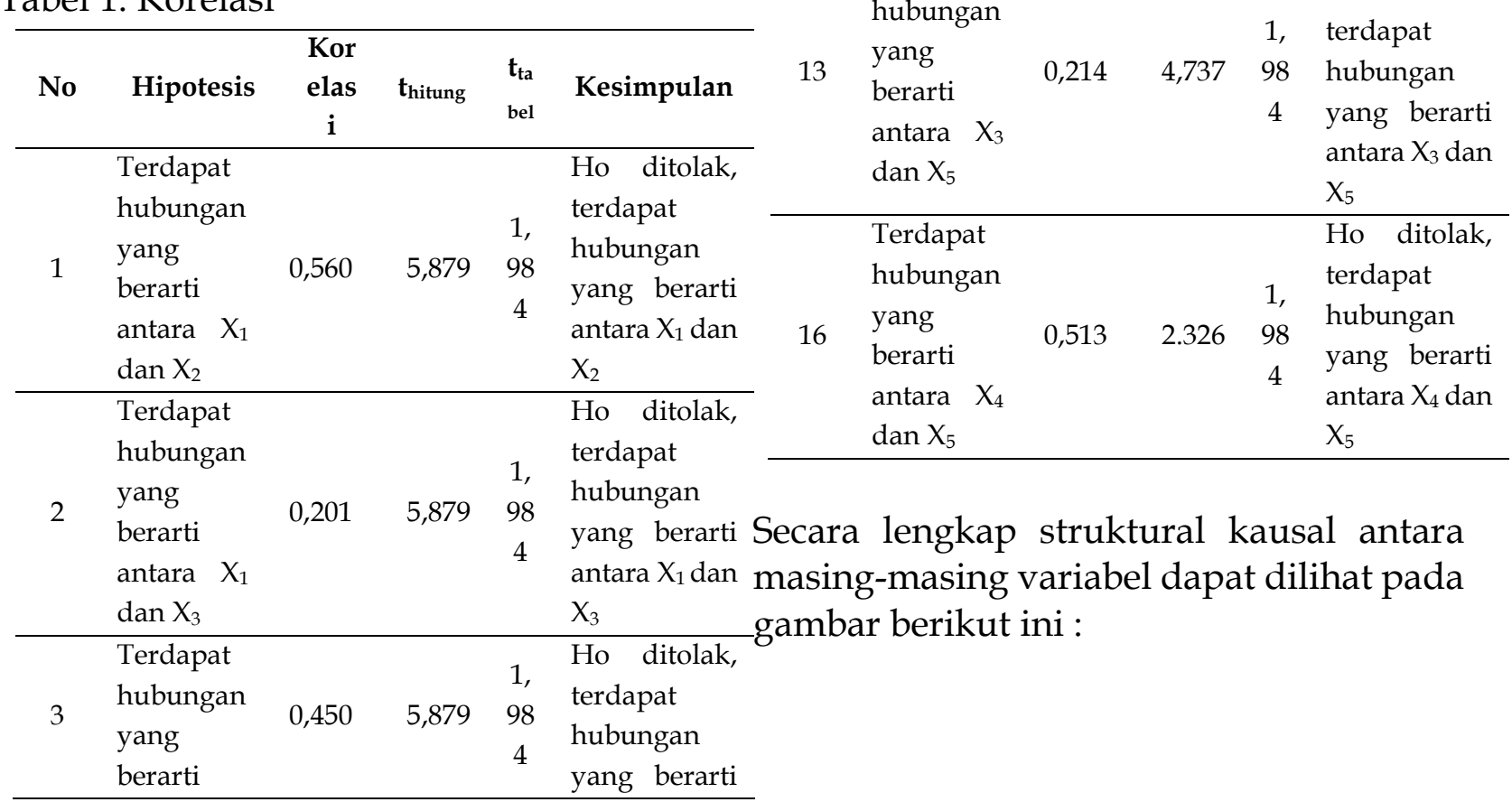

\begin{tabular}{|c|c|c|c|c|c|}
\hline & $\begin{array}{ll}\text { antara } & X_{1} \\
\text { dan } X_{4} & \\
\end{array}$ & & & & $\begin{array}{l}\text { antara } \mathrm{X}_{1} \text { dan } \\
\mathrm{X}_{4}\end{array}$ \\
\hline 4 & $\begin{array}{l}\text { Terdapat } \\
\text { hubungan } \\
\text { yang } \\
\text { berarti } \\
\text { antara } X_{1} \\
\text { dan } X_{5}\end{array}$ & 0,471 & 5,879 & $\begin{array}{c}1, \\
98 \\
4\end{array}$ & $\begin{array}{l}\text { Ho ditolak, } \\
\text { terdapat } \\
\text { hubungan } \\
\text { yang berarti } \\
\text { antara } X_{1} \text { dan } \\
X_{5}\end{array}$ \\
\hline 7 & $\begin{array}{l}\text { Terdapat } \\
\text { hubungan } \\
\text { yang } \\
\text { berarti } \\
\text { antara } X_{2} \\
\text { dan } X_{3}\end{array}$ & 0,306 & 3,086 & $\begin{array}{c}1, \\
98 \\
4\end{array}$ & $\begin{array}{l}\text { Ho ditolak, } \\
\text { terdapat } \\
\text { hubungan } \\
\text { yang berarti } \\
\text { antara } X_{2} \text { dan } \\
X_{3}\end{array}$ \\
\hline 8 & $\begin{array}{l}\text { Terdapat } \\
\text { hubungan } \\
\text { yang } \\
\text { berarti } \\
\text { antara } \quad X_{2} \\
\text { dan } X_{4} \\
\end{array}$ & 0,435 & 3,086 & $\begin{array}{c}1, \\
98 \\
4\end{array}$ & $\begin{array}{l}\text { Ho ditolak, } \\
\text { terdapat } \\
\text { hubungan } \\
\text { yang berarti } \\
\text { antara } X_{2} \text { dan } \\
X_{4}\end{array}$ \\
\hline 9 & $\begin{array}{l}\text { Terdapat } \\
\text { hubungan } \\
\text { yang } \\
\text { berarti } \\
\text { antara } X_{2} \\
\text { dan } X_{5}\end{array}$ & 0,523 & 3,086 & $\begin{array}{c}1, \\
98 \\
4\end{array}$ & $\begin{array}{l}\text { Ho ditolak, } \\
\text { terdapat } \\
\text { hubungan } \\
\text { yang berarti } \\
\text { antara } X_{2} \text { dan } \\
X_{5}\end{array}$ \\
\hline 12 & $\begin{array}{l}\text { Terdapat } \\
\text { hubungan } \\
\text { yang } \\
\text { berarti } \\
\text { antara } X_{3} \\
\text { dan } X_{4}\end{array}$ & 0,363 & 4,737 & $\begin{array}{c}1, \\
98 \\
4\end{array}$ & $\begin{array}{l}\text { Ho ditolak, } \\
\text { terdapat } \\
\text { hubungan } \\
\text { yang berarti } \\
\text { antara } X_{3} \text { dan } \\
X_{4}\end{array}$ \\
\hline 13 & $\begin{array}{l}\text { Terdapat } \\
\text { hubungan } \\
\text { yang } \\
\text { berarti } \\
\text { antara } X_{3} \\
\text { dan } X_{5}\end{array}$ & 0,214 & 4,737 & $\begin{array}{c}1, \\
98 \\
4\end{array}$ & $\begin{array}{l}\text { Ho ditolak, } \\
\text { tidak } \\
\text { terdapat } \\
\text { hubungan } \\
\text { yang berarti } \\
\text { antara } X_{3} \text { dan } \\
X_{5}\end{array}$ \\
\hline 16 & $\begin{array}{l}\text { Terdapat } \\
\text { hubungan } \\
\text { yang } \\
\text { berarti } \\
\text { antara } X_{4} \\
\text { dan } X_{5}\end{array}$ & 0,513 & 2.326 & $\begin{array}{c}1, \\
98 \\
4\end{array}$ & $\begin{array}{l}\text { Ho ditolak, } \\
\text { terdapat } \\
\text { hubungan } \\
\text { yang berarti } \\
\text { antara } X_{4} \text { dan } \\
X_{5}\end{array}$ \\
\hline
\end{tabular}




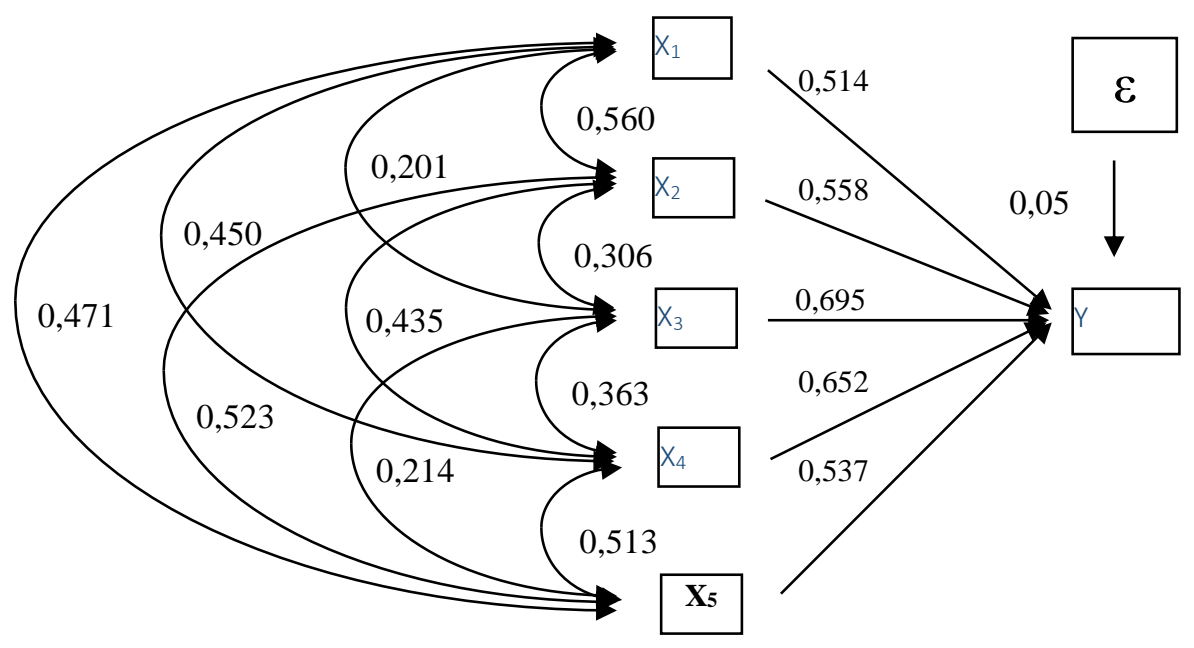

Gambar 2. Hubungan Kausal Antara Variabel $X_{1}, X_{2}, X_{3}, X_{4}, X_{5}$ dan $Y$

\section{KESIMPULAN DAN SARAN}

\section{Kesimpulan}

Dari penelitian yang telah dilakukan oleh penulis di Universitas Buddhi Dharma diperoleh beberapa kesimpulan dari hasil pengujian menunjukkan pengaruh langsung dan tidak langsung pelaksanaan variabel-variabel bauran promosi yang terdiri dari periklanan $\left(\mathrm{X}_{1}\right)$, promosi penjualan $\left(X_{2}\right)$, hubungan masyarakat $\left(X_{3}\right)$, penjualan tatap muka $\left(\mathrm{X}_{4}\right)$, dan pemasaran langsung $\left(\mathrm{X}_{5}\right)$.

Pengaruh bauran promosi, dari hasil perhitungan akhir memperlihatkan bahwa pengaruh bauran promosi baik Advertaising, personal seling, sales promotion, public relation dan direct marketing baik secara bersama-sama dan masing-masing memiliki pengaruh yang signifikan terhadap pengambilan Ekuitas Merk Universitas Buddhi Dharma.Secara umum bauran promosi yang mencakup periklanan, promosi penjualan, hubungan masyarakat, penjualan tatap muka berpengaruh terhadap ekuitas merek. Hal ini sesuai dengan tanggapan responden (Mahasiswa jurusan Manajemen di Universitas Buddhi Dharma) atas masingmasing sub program bauran promosi. Sub variabel bauran promosi yang memiliki pengaruh yang signifikan baik secara simultan maupun secara parsial terhadap ekuitas merek. Pengaruh program sales promotion dan public relation mempunyai pengaruh yang paling besar terhadap tingkat perubahan ekuitas merek.

\section{Saran}

Saran-saran yang dapat disampaikan dari hasil penelitian ini adalah sebagai berikut : Bagi Universitas Buddhi Dharma sebaiknya memfokuskan kebijakan pada Advertaising, personal seling, sales promotion, public relation dan direct marketing dikarenakan sangat berpengaruh terhadap ekuitas merek. Dapat diartikan bahwa perubahan sedikit saja pada Advertaising, personal seling, sales promotion, public relation dan direct marketing akan menyebabkan perubahan 
yang sangat berarti pada ekuitas merek perusahaan dikalangan mahasiswa.

Begitu juga pada elemen-elemen lain yang ada cukup dipertahankan saja karena pengaruhnya tidak signifikan. Dapat diartikan setiap perubahan pada faktor tersebut tidak menyebabkan perubahan yang cukup berarti pada ekuitas merek.

Bagi peneliti selanjutnya bisa meneliti tentang pengaruh lain yang dapat meningkatkan ekuitas merek. Pengaruh lain tersebut sangat besar jika dibandingkan dengan variabel-variabel bauran promosi yang telah penulis teliti sekarang ini.

\section{DAFTAR PUSTAKA}

Aaker, David, 1997, "Manajemen Ekuitas Merek." Jakarta : Mitra Utama

Belch, George E. And Michael A. Belch, 1998, Advertising And Promotion-An Integrated Marketing Communication Perspective

Cravens, David W, 2000, Strategig Marketing, $6^{\text {th }}$ Edition, Mcgraw-Hill Companies, Inc., Usa

Tjiptono, Fandy, 1997, Strategi Pemasaran, Edisi II, Yogyakarta.

Harun Al-Rasyid. 1994, "Dasar-dasar Statistika Terapan." PascasarjanaUNPAD, Jakarta

Kotler, Philip, 2002, Manajemen Pemasaran, Terjemahan Hendra Teguh, Ronny A. Rusli Dan Benyamin Molan, Edisi Milinium, Edisi Kesepuluh, Pt. Prenhallindo, Jakarta.

Nur Indriantoro, dan Bambang Supomo. 1999," Metodologi Penelitian Bisnis Untuk Akuntansi dan Manajemen"Jogjakarta : BPFE
Nirwana Sitepu. 1994, "Analisis Jalur." UPT Jurusan Statistik, FMIPA UNPAD, Jakarta.

Josephine, Y., \& Riki, R. (2017). Implementasi eBudgeting Terhadap Kinerja PT Primer Eka Properti Melalui Pengendalian Internal. TechE, 1(1), 1-6. Retrieved from https:/ /jurnal.buddhidharma. ac.id/index.php/te/article/view/1 $\underline{1}$

Sekaran, Uma. 2000. Research Methods For Business, A Skill-Building Approach, Third Edition, Jonh Wiley \& Sons, Inc.

$\underline{\text { Tesis }}$

Robert M. M. Sitorus, "Pengaruh Bauran Promosi Terhadap Ekuitas Merek Studi pada MQ Cafe Bandung", Tesis UNPAD. 